\title{
Herbal Medicines Used in the Treatment of Typhoid in the Ga East Municipality of Ghana
}

\author{
Emelia Oppong Bekoe $^{1^{*}}$, Christian Agyare $^{2}$, Joseph Sarkodie ${ }^{1}$ \\ and Dorothy Dadebo ${ }^{3}$ \\ ${ }^{1}$ Department of Pharmacognosy and Herbal Medicine, School of Pharmacy, University of Ghana, \\ Ghana. \\ ${ }^{2}$ Department of Pharmaceutics, Faculty of Pharmacy and Pharmaceutical Sciences, Kwame Nkrumah \\ University of Science and Technology, Ghana. \\ ${ }^{3}$ Department of Pharmaceutics and Microbiology, School of Pharmacy, University of Ghana, Ghana.
}

Authors' contributions

This work was carried out in collaboration among all authors. Author EOB designed and supervised the study and wrote the first draft of the manuscript. Author DD performed the market survey and analysed the data. Authors CA and JS managed the literature searches and approved the final manuscript.

\section{Article Information}

DOI: $10.9734 / / J T D H / 2017 / 31448$ Editor(s):

(1) Tetsuji Yamada, Chair and Professor of Health Economics, Center for Children and Childhood Studies, Rutgers University, the State University of New Jersey, USA.

(2) Thomas I. Nathaniel, Department of Biomedical Sciences, School of Medicine - Greenville University of South Carolina, Greenville, USA.

(3) Triveni Krishnan, Division of Virology, National Institute of Cholera and Enteric Diseases, Kolkata, India. (4) Shankar Srinivasan, Department of Health Informatics, University of Medicine \& Dentistry of New Jersey, USA.

(1) James Adams, University of Southern California, USA (2) Ngono Ngane Rosalie Annie, University of Douala, Cameroon. (3) Luis Eduardo Diaz, Universidad de La Sabana, Colombia. Complete Peer review History: http://www.sciencedomain.org/review-history/19439

Original Research Article

Received $6^{\text {th }}$ January 2017

Accepted $9^{\text {th }}$ March 2017

Published 9 $^{\text {th }}$ June 2017

\section{ABSTRACT}

In Ghana, majority of the people patronize herbal medicines for the treatment of both chronic and acute ailments as well as infectious and non-infectious diseases. As such, the use of herbs as medicines in the treatment of enteric (typhoid) fever is very widespread.

Aims: This study therefore investigates anti-typhoidal herbal medicinal formulations that are for sale on the Ghanaian market with regards to the contents on the product labels and assesses the various active plant components in the light of documented evidence of their use in the treatment of typhoid. 
Methodology: Herbal products for the treatment of typhoid were sampled from herbal medicine shops and pharmacies and assessed for the type of formulation, plant and non-plant constituents, dosage, indications, treatment duration and contraindications.

Results: Majority of the products $(87 \%, n=16)$ had registration numbers whilst $13 \%$ had none. These anti-typhoid formulations were simultaneously recommended for the treatment of malaria (56\%) (9 out of 16 products), jaundice (31\%), various types of pains (body pains, headache, menstrual pains) $(8 \%)$, stress $(8 \%)$ and fatigue $(8 \%)$. All the preparations had more than one plant as its active constituent. Forty-four percent (44\%) contained 2 plants species as the active ingredients, $37 \%$ contained between 3 to 5 plant species, $13 \%$ contained 6 to 10 plant species and $6 \%$ contained more than 10 plant species. The most frequently occurring active plant constituents of these products were Carica papaya L. (Caricaceae), Morinda lucida (Rubiaceae), Citrus aurantifolia (Rutaceae), Vernonia amygdalina (Compositae) and Azadirachta indica (Meliaceae).

Conclusion: In all, thirty-four different plant species belonging to 25 families were found to be present in these products. A literature search on the plants species showed that their traditional use in the treatment of typhoid is well documented and hence their resulting formulations may as well be very effective.

Keywords: Typhoid fever; anti-typhoid herbal medicinal formulations; active plant constituents.

\section{ABBREVIATION}

\section{NTS : Nontyphoidal Salmonella}

\section{INTRODUCTION}

Typhoid fever, a common and sometimes fatal infection of both adults and children that causes bacteremia and inflammatory destruction of the intestine and other organs, is endemic in countries, especially throughout Asia and Africa [1]. Chloramphenicol has been the treatment of choice for typhoid fever for 40 years, but the widespread emergence of multi-drug resistant Salmonella typhi (resistant to ampicillin, chloramphenicol, and trimethoprimsulfamethoxazole) has necessitated the search for other therapeutic options [2]. Currently ciprofloxacin is the drug of choice in the treatment of enteric fever in Ghana. Alternatives such as azithromycin and ceftriazone are also recommended [3].

Typhoid fever, caused by the bacterium Salmonella enterica serovar typhi (S. typhi), has become rare in industrialized countries, yet it remains a major cause of enteric disease in children in developing countries [1], resulting in an estimated incidence of 50 cases per 100,000 persons per year, predominantly in young school-age children [4]. Globally, it is estimated that typhoid accounts for 16 million cases each year, resulting in over 600,000 deaths [5]. Typhoid fever therefore continues to be a public health problem in sub-Saharan Africa. The disease is common in developing countries and concomitant with poor public health and low socio economic indices [6]. Residents of poor communities lacking good water and sanitation system are those mostly affected. It is estimated that a total of 400,000 cases occur annually in Africa, with an incidence of 50 per 100,000 persons per year $[7,8]$.

- In Sub-Saharan Africa invasive nontyphoidal salmonella (NTS) is also a major cause of bacteremia in adults and children; with an estimated occurrence of $175-388$ cases per 100,000 in children and 200-7500 cases per 100,000 in HIV infected adults annually. In Ghana, typhoid fever ranks among the leading 20 causes of outpatient illness, accounting for $0.92 \%$ of hospital admissions [9].

It is estimated that over $80 \%$ of people in developing countries use herbal medicines for their primary healthcare [10]. As much as $70 \%$ of Ghana's population is estimated to rely on traditional medicine for their primary healthcare [11]. Correspondingly, majority of patients in Ghana patronize herbal medicines for the treatment of typhoid fever, hence the availability of a wide range of herbal medicines used in the treatment of typhoid fever. Concomitantly, these same medicines are very often used to treat other common ailments such as malaria, jaundice etc.

The widespread patronage of these herbal medicines explains the high rate of advertisements of these products on radio, television and other social media. There is an estimation of one traditional medicine practitioner for every 400 people, compared with one allopathic doctor for every 12,000 people [11]. 
Apparently, majority of the people patronize herbal medicines for the management of various disease conditions [11]. Most of the herbal preparations are produced and marketed by traditional medicine practitioners, they therefore have to be recommended for providing healthcare to Ghanaian indigenes long before the advent of modern medicine. This study therefore sought to determine the various types of herbal medicinal formulations used in the treatment of typhoid fever on the Ghanaian market and appraises these products via their product labels.

\section{METHODS}

\subsection{Drug Collection}

Between the periods of January - March of 2016, fifteen Pharmacies and six Herbal Medicines Retail Shops within the Ga East Municipality in the Greater Accra Region of Ghana were visited; and all herbal medicines indicated for the treatment of typhoid fever were purchased. Only herbal medicines that had Food and Drugs Authority of Ghana registration numbers were bought. Those without registration numbers were however noted. Sampling was stopped when no new anti-typhoid formulations were being found.

\subsection{Sampling Site}

All the herbal products were collected from Haatso, Dome and Ashongman communities, located within the $\mathrm{Ga}$ East Municipality of the Greater Accra Region of Ghana ( $5^{\circ} 44^{\prime} 17^{\prime \prime} \mathrm{N}, 0^{\circ}$ 11' 42" W5.738056, -0.195). According to the Ghana Statistical Service, 2010 Population and Housing Census on the Ga East Municipality, it is located at the northern part of the Greater Accra Region and covers a land area of about 85.7 square kilometers. The population is almost 148,000. Males constitute $49 \%$ and females represent $51 \%$. It has $40.3 \%$ of the population below 20 years. The population density of the $\mathrm{Ga}$ Municipal area stands at 1,725 persons per square kilometer. Households in the Municipal Area are more of extended family $(56.2 \%)$ than nuclear family (43.8\%). Almost $97.5 \%$ of the population in the Municipal Area is Ghanaians. Nearly $60 \%$ are literate. Of the employed population, $35.1 \%$ are engaged as service and sales workers while $22.6 \%$ are craft workers and traders [12].

\subsection{Appraisal of Product Labels}

The products were given unique identification codes and were appraised with regard to contents on their labels. Information used to assess the product labels included the presence or absence of Food and Drugs Authority of Ghana registration numbers, place of manufacture, type of formulation (solid or liquid), the plant and/or non-plant constituents present, the adult dosage per day, the various indications and duration of treatment, and their contraindications. Data were analyzed in Microsoft Excel and have been presented as graphs. The acceptable scientific names of the active plants constituents as stated on the product labels were determined by searching in online taxonomic sources such as The Plant List (TPL) (http://www.theplantlist.org/) and the International Plant Name Index (www.ipni.org).

\section{RESULTS}

Of all the anti-typhoidal finished formulations sampled from the market, most had been registered by the Food and Drugs Authority of Ghana, and this was indicated by the presence of registered numbers on the products. Fig. 1, displays the percentage of products that had Food and Drugs Authority of Ghana registered numbers and those that did not have them.

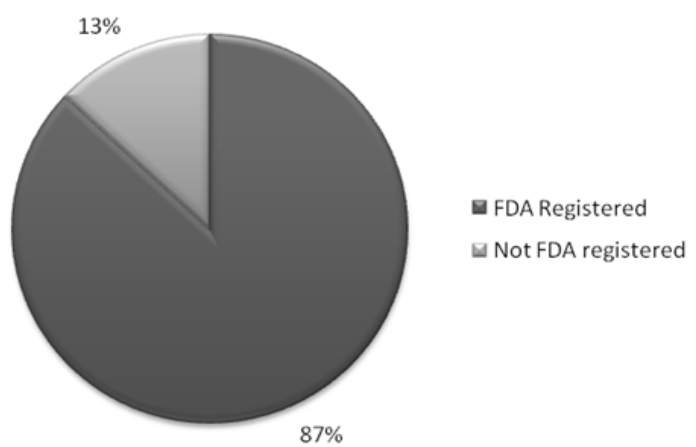

Fig. 1. Proportion of Anti-typhoidal herbal medicinal products sold within the Ga East Municipality having Food and Drugs Authority of Ghana registration numbers and those that did not have, as percentages of the number of products $(n=16)$

The cost of these herbal preparations ranged from 7 to 15 Ghana Cedis, with an average cost of 10 Ghana Cedis per product. All the herbal preparations were formulated as liquid decoctions, ranging from $180 \mathrm{~mL}$ to $1000 \mathrm{~mL}$ volumes. The adult daily doses on these products ranged from $45 \mathrm{~mL}$ to $300 \mathrm{~mL}$; with an average volume of $157 \mathrm{~mL}$ to be consumed daily. Measurements of the daily doses were stated as tablespoonfuls, millilitres or in most instances a 
combination of both tablespoonfuls and millilitres. Fig. 2 summarizes the percentage of products labeled as such.

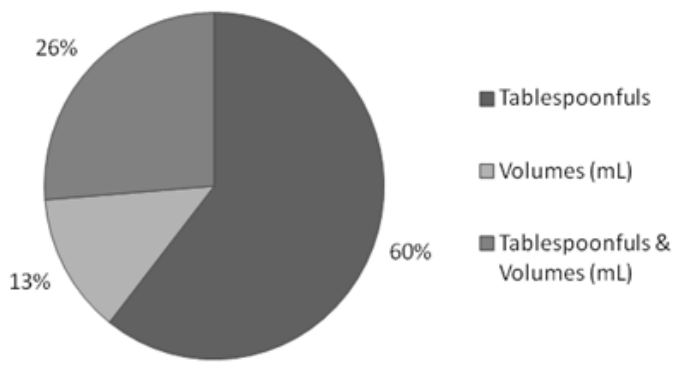

Fig. 2. Measurement of doses of anti-typhoid herbal formulations; tablespoonfuls, volumes $(\mathrm{mL})$ or stated as both tablespoonfuls and volumes $(\mathrm{mL})$. Results are presented as percentages of the total number of products $(n=16)$

All the products encountered on the market were locally manufactured within the country (Ghana), with $71 \%$ manufactured in Accra and the other $19 \%$ manufactured within the Ashanti Region of Ghana.

The duration of treatment as indicated on the product label ranged from one to three weeks. The duration of treatment was not stated on $38 \%$ of the products. The herbal preparations sold for the treatment of typhoid were in all cases simultaneously used to treat at least one other disease condition, namely malaria, jaundice, pains (body pains, menstrual pains and headache), fatigue and stress. Fig. 3 displays the percentages of these products that were indicated for the simultaneous treatment of particular conditions. On $56 \%$ of the products, indications for the treatment of malaria were also made, while on $31 \%$ of the products, treatment of jaundice was also recommended.

An assessment of the contraindications for these products showed that all the products were contraindicated in pregnancy, lactating mothers and children below either 6 yrs or 12 yrs of age. No other groups of people were indicated as being contraindicated.

On all the products, the active components were stated to be plant extracts. No artificial constituents or excipients in the form of preservatives, flavours or sweeteners were indicated to be present.

The number of different plant species used to formulate these products ranged from two to twelve different plants. The products contained an average of four different plants species per formulation. Fig. 4 displays a breakdown of the percentage of products containing the different number of plant species. Some particular plant species were identified to be present in a number of these formulated products while others were unique to only one product. Table 1 contains the various plant species identified in the herbal preparations. A total of 39 plant species belonging to 25 families were identified to be used for the formulation of herbal medicines used for the treatment of typhoid fever in Ghana.

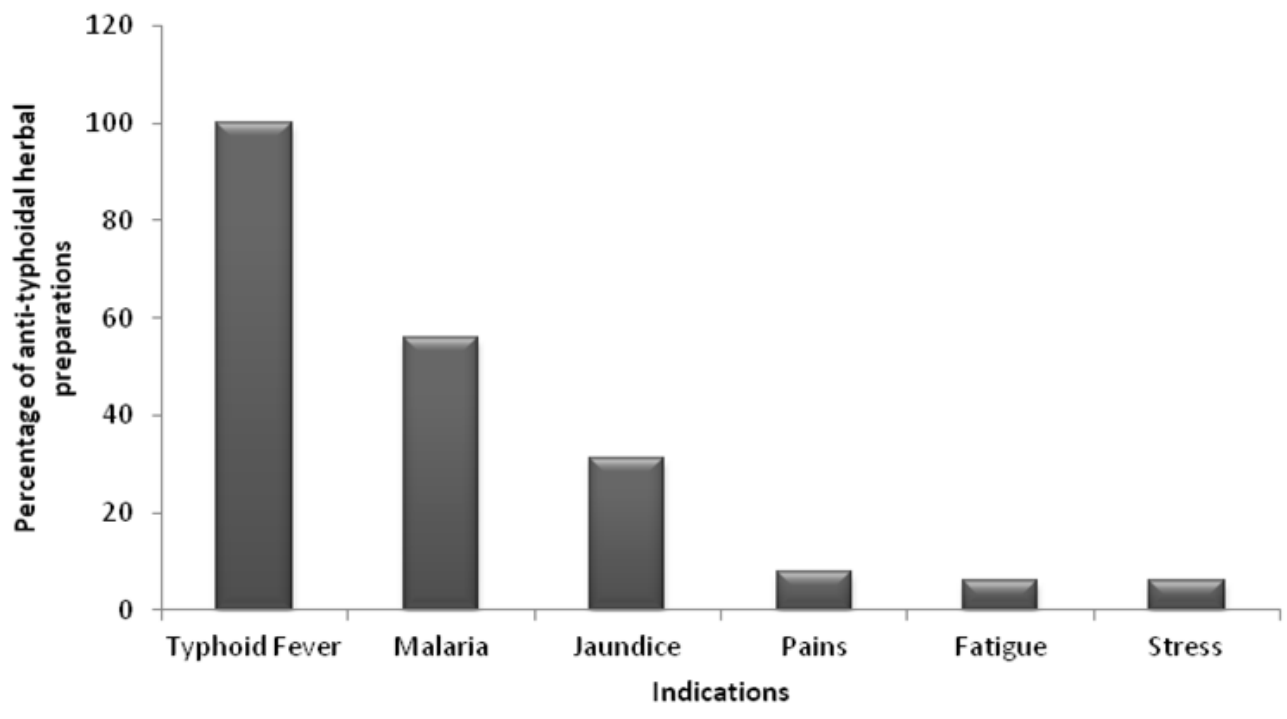

Fig. 3. Indications for which anti-typhoidal herbal medicinal preparations were recommended 


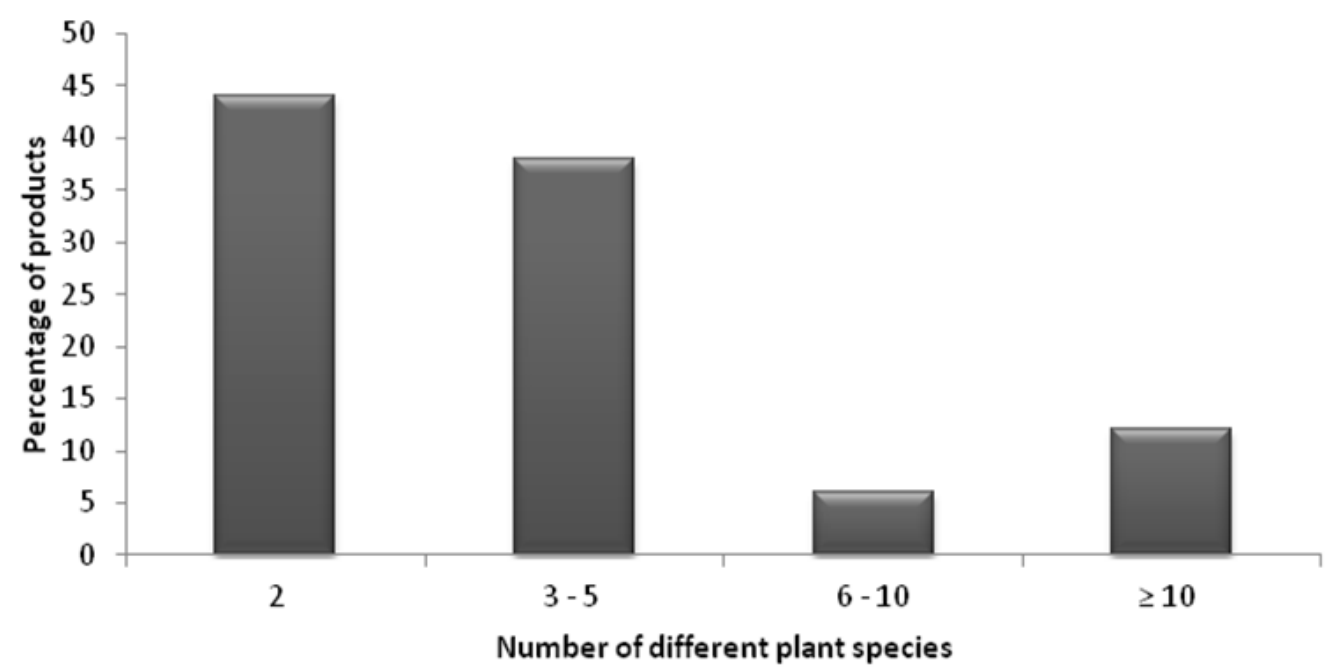

Fig. 4. Distribution of number of plant species in products

Table 1. Active plant constituents in anti-typhoid herbal medicinal formulations. Group I (very frequently occurring plant species, recorded more than 3 - 6 times on the products) and Group II (less frequently occurring plant species, recorded 1-2 times on the products)

\begin{tabular}{|c|c|}
\hline \multicolumn{2}{|c|}{ Group I } \\
\hline Carica papaya L. (family Caricaceae) & Morinda lucida Benth. (family Rubiaceae) \\
\hline Citrus aurantifolia (family Rutaceae) & Vernonia amygdalina Delile. (family Compositae) \\
\hline Azadirachta indica A. Juss (family Meliaceae) & Cassia alata L.(family Caesalpiniaceae) \\
\hline $\begin{array}{l}\text { Khaya senegalensis (Desv.) A. Juss (family } \\
\text { Meliaceae) }\end{array}$ & Momordica charantia L. (family Curcubitaceae) \\
\hline \multicolumn{2}{|c|}{ Group II } \\
\hline Persea americana Mill. (family Lauraceae) & Cocos nucifera L. (family Araceae) \\
\hline $\begin{array}{l}\text { Phyllanthus fratenus G.L. Webster (family } \\
\text { Phyllantiaceae) }\end{array}$ & Khaya ivorensis A. Cheo (family Meliaceae) \\
\hline Trema orientalis L. Blume (family Cannabeceae) & $\begin{array}{l}\text { Cryptolepis sanguinolenta (Lindl.) Schltr (family } \\
\text { Apocynaceae) }\end{array}$ \\
\hline Psidium guajava L. (family Myrtaceae) & Cymbopogon citrates DC. (family Apocynaceae) \\
\hline $\begin{array}{l}\text { Pycnanthus angolensis (Welw.) Warb, (family } \\
\text { Myristicaceae) }\end{array}$ & Lantana camara L. (family Verbanaceae) \\
\hline Rauwolfia vomitoria Afzel (family Anarcadiaceae) & Mangifera indica L. (family Anarcadiaceae) \\
\hline Spondiasis mombin L.(family Anacardiaceae) & Cassia sieberiana DC. (family Leguminosae) \\
\hline Carapa procera DC. (family Meliaceae) & Nauclea latifolia Sm. (family Rubiaceae) \\
\hline Bidens pilosa L. (family Asteraceae ) & Paullinia pinnata (family Sapindaceae) \\
\hline Alstonia boonei De Wild (family Apocynaceae) & Zingiber officinale Roscoe (family Zingiberaceae) \\
\hline Aloe schweinfurthii Baker (family Aloaceae) & $\begin{array}{l}\text { Cnestis ferruginea Vahl ex DC.(family } \\
\text { Connarceae) }\end{array}$ \\
\hline Ocimum gratissimum (family Lamiaceae) & Vitex grandifolia Gürke (family Lamiaceae) \\
\hline Cassia siamea Lam.(family Caesalpiniaceae) & Anthocleista nobilis G. Don (family Gentianaceae) \\
\hline $\begin{array}{l}\text { Several errors in the names of the active plant } \\
\text { constituents were discovered. A number of plant } \\
\text { names on the product labels could not be readily } \\
\text { dentified or were wrongly spelt. Some labels } \\
\text { nentioned only the plant genus but failed to state }\end{array}$ & $\begin{array}{l}\text { the particular species. After online verification } \\
\text { the plant names, literature search showed tha } \\
\text { out of the } 39 \text { plants identified, anti-typhoid activit } \\
\text { has been documented for at least } 89 \% \\
\text { (Table } 2 \text { ). }\end{array}$ \\
\hline
\end{tabular}


Table 2. Literature review on plants

\begin{tabular}{|c|c|}
\hline Species & Cross-reference \\
\hline Aloe schweinfurthii & No reference found. \\
\hline Alstonia boonei & $\begin{array}{l}\text { The ethanol extract of this plant showed better antibacterial activity than the } \\
\text { water, methanol and hexane extracts against } S \text {. typhi [13]. }\end{array}$ \\
\hline $\begin{array}{l}\text { Anthocleista nobilis } \mathrm{G} \text {. } \\
\text { Don }\end{array}$ & $\begin{array}{l}\text { A. nobilis is commonly used for treating typhoid fever, amongst several other } \\
\text { diseases in North-Central Nigeria [14]. }\end{array}$ \\
\hline Anthocleista vogelii & $\begin{array}{l}\text { Both the ethanol and aqueous extracts of the leaves had good antibacterial } \\
\text { effect against } S \text {. typhi when compared with Chloramphenicol [15]. }\end{array}$ \\
\hline Azadirachta indica & $\begin{array}{l}\text { When the antibacterial activity of } A \text {. indica (Neem) was evaluated, the } \\
\text { methanolic leaf extracts showed the highest zone of inhibition against } \\
\text { salmonella as compared with other extracts [16]. }\end{array}$ \\
\hline Bidens pilosa & $\begin{array}{l}\text { B. pilosa is part of a number of plant species traditionally used in the } \\
\text { management of typhoid fever in the Bamboutos Division of the West Region } \\
\text { of Cameroon [17]. }\end{array}$ \\
\hline Carapa procera & $\begin{array}{l}\text { C. procera is part of the Cameroonian pharmacopeia which when evaluated } \\
\text { against gastroenteritis-causing bacteria including } S \text {. typhi, the crude extracts } \\
\text { and methanolic fractions of the leaves and bark were active against four (4) } \\
\text { bacterial species including } S \text {. typhi and } S \text {. paratyphi. Active extracts and } \\
\text { fractions gave MICs ranging from } 2.5 \text { to } 10 \mathrm{mg} / \mathrm{mL} \text { [18]. }\end{array}$ \\
\hline Carica papaya & $\begin{array}{l}\text { The seeds of } C \text {. papaya are effective against } E \text {. coli, Salmonella and } \\
\text { Staphylococcus infections, where the leaf and stem extracts have } \\
\text { demonstrated high activities against Gram negative bacteria and Gram } \\
\text { positive bacteria, with the highest activity demonstrated against S. typhi. This } \\
\text { study therefore recommended that } C \text {. papaya may be used for the treatment } \\
\text { of gastroenteritis, urethritis, otitis media, typhoid fever and wound infections } \\
\text { [19]. }\end{array}$ \\
\hline $\begin{array}{l}\text { Cassia alata (Senna } \\
\text { alata) }\end{array}$ & $\begin{array}{l}\text { The Bamboutos division in Cameroon uses this plant in the treatment of } \\
\text { typhoid. This plant showed the highest zones of inhibition with diameter of } 24 \text {, } \\
22.5 \text { and } 20.5 \mathrm{~mm} \text { against } S \text {. paratyphi } A \text {, S. paratyphi B and S. typhi } \\
\text { respectively at } 160 \mathrm{mg} / \mathrm{mL} \text { concentration [20]. }\end{array}$ \\
\hline $\begin{array}{l}\text { Cassia siamea (Senna } \\
\text { siamea) }\end{array}$ & The ethanol and ethyl acetate extracts showed inhibition against S. typhi [21]. \\
\hline Cassia sieberiana & $\begin{array}{l}\text { The leaves or bark are boiled in water or alcohol, and drunk over a } \\
\text { period of time depending on the severity to treat typhoid fever [14]. }\end{array}$ \\
\hline Citrus aurantifolia & $\begin{array}{l}\text { This plant is widely used in West Africa for its antimicrobial activity against } \\
\text { gastrointestinal pathogens including Salmonella }[22,23] \text {. }\end{array}$ \\
\hline Cnestis ferruginea & $\begin{array}{l}\text { The ethanol extracts of the stem of } C \text {. ferruginea demonstrated activity } \\
\text { against various bacteria including Salmonella. MIC and MBC against the } \\
\text { bacterial isolates were in the range of } 3.2-6.3 \mathrm{mg} / \mathrm{mL} \text { [24]. }\end{array}$ \\
\hline Cocos nucifera & $\begin{array}{l}\text { C. nucifera mesocarp powder showed very high activity against Salmonella } \\
\text { typhi [25]. }\end{array}$ \\
\hline Cryptolepis & A $2 \mathrm{mg} / \mathrm{mL}$ each of $70 \%$ ethanol, hot and cold aqueous extract of $C$. \\
\hline sanguinolenta & $\begin{array}{l}\text { sanguinolenta exhibited activity against } S \text {. typhimurium, three strains each of } \\
\text { Salmonella typhi and several other microorganisms [26]. }\end{array}$ \\
\hline Cymbopogon citratus & $\begin{array}{l}\text { C. citrates was documented in an ethnomedicinal survey of plants used for } \\
\text { the treatment of typhoid fever in ljebu Ode Local Government Area of Ogun } \\
\text { State Nigeria [27]. It was also observed in another study to possess high } \\
\text { antimicrobial activity against S. typhi [28]. }\end{array}$ \\
\hline Khaya senegalensis & $\begin{array}{l}\text { The ethanol and aqueous extracts of the stem bark extracts of } K \text {. } \\
\text { senegalensis showed activity against } S \text {. typhi at a concentration of } 50 \mathrm{mg} / \mathrm{mL} \\
\text { with an inhibition zone of } 15 \mathrm{~mm} \text { respectively [29]. }\end{array}$ \\
\hline Khaya ivorensis & $\begin{array}{l}\text { It was observed that when mixed with black peppercorns it can be used to } \\
\text { treat diarrhea and dysentery. A bark concoction is used as a drink or bath for } \\
\text { back pains and as a lotion for rheumatism [30]. }\end{array}$ \\
\hline
\end{tabular}




\begin{tabular}{|c|c|}
\hline Species & Cross-reference \\
\hline Lantana camara & L. camara has activity against $S$. gallinarum with MIC starting at $5 \mathrm{mg} / \mathrm{mL}$ [31]. \\
\hline Mangifera indica & $\begin{array}{l}\text { Aqueous extract of } M \text {. indica showed good anti-salmonella activity against } \\
\text { clinical isolates of } S \text {. typhus, with } 98.8 \% \text { inhibition at } 200 \mu \mathrm{g} / \mathrm{mL} \\
\text { concentration. IC50 required for killing Salmonella ranged from } 101.3 \text { to } 800 \\
\mu \mathrm{g} / \mathrm{mL}[32] \text {, other studies have also supported the anti-typhoid activity of this } \\
\text { plant [33]. }\end{array}$ \\
\hline Momordica charantia & $\begin{array}{l}\text { Marked reduction in infection level was observed in rats treated with extracts } \\
\text { from } M \text {. charantia when compared to standard drugs [34]. }\end{array}$ \\
\hline Morinda lucida & $\begin{array}{l}\text { The water and chloroform extracts of leaves of } M \text {. lucida has produced } \\
\text { antibacterial effects comparable to those of standard antibiotics against } S \text {. } \\
\text { typhi and other microorganism [35]. The stem bark, roots and leaves infusions } \\
\text { are also documented to be used as an anti-dysentery [36]. }\end{array}$ \\
\hline Nauclea latifolia & $\begin{array}{l}\text { The aqueous and alcoholic extracts of the leaves and roots of } N \text {. latifolia } \\
\text { showed no appreciable inhibitory effect against S. typhi [37]. }\end{array}$ \\
\hline $\begin{array}{l}\text { Ocimum gratissimum } \\
\text { (Ocimum viride) }\end{array}$ & $\begin{array}{l}\text { The steam distillation extract of } O \text {. gratissimum has shown activity at } 0.01 \% \\
\text { against } S \text {. typhimurium and } 0.001 \% \text { against } S \text {. typhi. The cold water, hot } \\
\text { water }\left(100^{\circ} \mathrm{C}\right) \text {, ethanol and chloroform extracts of Ocimum gratisssimum } \\
\text { leaves also showed antibacterial potential against some pathogenic bacteria } \\
\text { known to cause diaorrhoea; Staphylococcus aureus, Escherichia coli, Shigella } \\
\text { sp. and Salmonella } s p .[38,39] \text {. }\end{array}$ \\
\hline Paullinia pinnata & $\begin{array}{l}\text { No reference found for hypertension. This plant is however useful in } \\
\text { traditional medicine for prophylaxis and cure of several diseases }[40,41] \text {. }\end{array}$ \\
\hline Persea americana & $\begin{array}{l}\text { The ethyl acetate, chloroform and methanol extracts did not demonstrate } \\
\text { pronounced activity against S. typhi [42]. }\end{array}$ \\
\hline Phylanthus fratenus & $\begin{array}{l}\text { The methanol extract of the root of } P \text {. fraternus showed maximum } \\
\text { antibacterial activity against } S \text {. typhi B with a zone of inhibition of } 11 \mathrm{~mm} \text { and } \\
\text { minimum activity against } S \text {. typhi A, with a zone of inhibition of } 10 \mathrm{~mm} \text { [43]. }\end{array}$ \\
\hline Psidium guajava & $\begin{array}{l}\text { The administration of } 10-30 \mathrm{mg} / 100 \mathrm{~g} \text { of the aqueous extract of } P \text {. guajava to } \\
\text { S. typhi infected rats over } 12 \mathrm{~h} \text { through the oral route produced a recovery } \\
\text { within seven days [44]. }\end{array}$ \\
\hline Pycnanthus angolensis & Methanol leaf extract caused inhibition against Salmonella [45]. \\
\hline Rauwolfia vomitoria & $\begin{array}{l}\text { R. vomitoria has a lot of medical potential in curing and preventing ailments } \\
\text { including typhoid [46]. }\end{array}$ \\
\hline Spondiasis mombin & $\begin{array}{l}\text { The aqueous and organic solvent extracts of fresh leaves of } S \text {. mombin } \\
\text { exhibited anti-microbial activity against } S \text {. typhi [47]. }\end{array}$ \\
\hline Trema orientalis & $\begin{array}{l}\text { Ethnomedicinal studies on Trema orientalis Linn. Blume (Ulmaceae) have } \\
\text { shown that it is used by traditional practitioners to treat several ailments viz. } \\
\text { diabetes mellitus, respiratory diseases, oliguria, and malaria }[48,49] \text {. }\end{array}$ \\
\hline Vernonia amygdalina & $\begin{array}{l}\text { Aqueous, ethanol and acetone extracts of } V \text {. amygdalina leaf, stem and roots } \\
\text { were tested at a concentration of } 100 \mathrm{mg} / \mathrm{mL} \text { against antibiotic-resistant } \\
\text { Salmonella species. Aqueous extracts of the leaf, stem and roots showed no } \\
\text { activity against antibiotic resistant Salmonella isolate, while the ethanol and } \\
\text { acetone extracts showed activity rates of } 20 \% \text { and } 17 \% \text { for roots, } 14.3 \% \text { and } \\
12.9 \% \text { for stem, and, } 15.7 \% \text { and } 11.4 \% \text { for leaf [44]. The anti-Salmonella } \\
\text { activity has been further confirmed by the ethanolic extract [50,51]. }\end{array}$ \\
\hline Vitex grandifolia & $\begin{array}{l}\text { Ethanol extracts demonstrated broad spectrum antibacterial activity against } \\
\text { Salmonella [52]. }\end{array}$ \\
\hline Zingiber officinale & $\begin{array}{l}\text { Soybean oil extract of ginger showed high zone of inhibition }(11.67 \pm 1.53 \mathrm{~mm}) \\
\text { against Salmonella spp [53] }\end{array}$ \\
\hline
\end{tabular}

\section{DISCUSSION}

The wide spread use of herbal medicines in the treatment of typhoid in Ghana gives a little indication of how widespread herbal medicines are used in Ghana. An estimated $80 \%$ of rural villagers in southern Ghana rely on plants as their main medicinal source [54]. The widespread use of herbal medicines in the coastal areas of Ghana, which includes Accra is attributed to 
rapid urbanization in an area with a high level of endemic plant taxa and a population heavily dependent on herbal medicines for their primary health care [55].

The fact that all these products were manufactured locally could be indications of how traditional herbal medicines are widely used within this area and the widespread belief in the efficacy of these herbs. This may also indicate the high level of patronage of these products and the availability of the various plant species used in the production of these products. All the products were formulated as liquid decoctions. This could be indicative of probably the preference for liquid formulation by the consumers or as a result of the manufacturers lacking sophisticated techniques to produce the other dosage forms. Most manufacturers of herbal medicines in Ghana are believed to be small to medium scale businesses.

The daily dosage of these products ranged from 45 to $300 \mathrm{~mL}$. These daily volumes are quite high, and may be an indication that the products can be better formulated so that the daily doses are smaller in volumes. This may require standardization of the preparation to increase the concentration of the active ingredients in the final products resulting in improvements in the quality [56]. This will result in a decrease in the final product volumes which currently ranges from 180 - $1000 \mathrm{~mL}$. Only two out of the 16 products provided measuring cups. A lack of standardized measuring instruments will promote inaccurate measurement of the medicines. Measuring spoons and cups can probably be included in all the products and the dosage stated in millilitres to enhance accurate measurement of doses [57].

The cost of these herbal preparations ranged from 7 to 15 Ghana Cedis, with an average cost of 10 Ghana Cedis per product. It is generally believed that herbal medicines are inexpensive [58], however, for most of these products more than one bottle of medication will need to be taken before one can complete the recommended duration of treatment. Hence a critical cost analysis will need to be made to really determine whether the costs of these herbal preparations are lower or higher when compared with the available alternative orthodox drugs such as ciprofloxacin which is the drug of choice for treating typhoid in Ghana [3].

The duration of treatment as indicated on the product labels ranged from one to three weeks. On $38 \%$ of the products, the duration of treatment was not stated at all. This puts the patient at a high risk of either under dosage or over dosage of the medicine. Under dosage could lead to treatment failure and over dosage may increase the chance of toxicity. An assessment of the duration of treatment and the daily dosage showed that majority of these products will need more than one product to be able to complete the recommended duration of treatment.

The anti-typhoid herbal formulations were simultaneously used for the treatment of malaria, jaundice, pains (body pains, menstrual pains and headache), fatigue and stress. A lot of Ghanaians accept that one herbal medicine could be the cure for many ailments and this notion may be the reason for which high numbers of plant species (up to 12) is found in each formulation. An average of 4 different plant species were used in formulating these products. The inclusion of several plants could mean that the products were probably formulated to multipurposely treat several ailments. Some plants on their own are also multi-purpose medicinal plants [59]. Azadirachta indica [54], Vernonia amygdalina [60], Momordica charantia [61] etc., are all plants documented to have multipurpose medicinal actions and available in these preparations.

The presence of a wide range of plant species [40] give a snapshot of the country's medicinal flora and, reflect the concerns about health and illness and the importance of traditional medicine among Ghanaians [62]. However, mistakes in the names of the plant species will need to be critically checked to aid in correct identification of the components.

In Ghana, typhoid fever ranks among the leading 20 causes of outpatient illness, accounting for $0.92 \%$ of hospital admissions [9]. Malaria on the other hand remains hyper endemic in Ghana and is the single most important cause of mortality and morbidity especially among children under five years, pregnant women and the poor [63]. These are therefore two prevalent infections in Ghana. The rationale to combine several active plants extracts is in itself not a bad idea since some plant species may also have been combined in these preparations to enable the individual components work synergistically to increase the overall effectiveness of the preparation. In traditional medicine, whole plant extracts or mixtures of plants are used rather than isolated compounds. There is the evidence that some 
crude plant extracts have greater in vitro or/and in vivo activities than isolated constituents at an equivalent dose [64]. Studies will however have to be conducted on these herbal formulations to ascertain stability of the active components, physical and chemical interactions between the various components, and safety in consuming such high numbers of different extracts (compounds). On the average, each plant extract may contain several of chemical compounds.

From another perspective, these plants extracts may be combined because the manufacturers may have very little or no clue as to the active components of the extracts. It may therefore be recommended that bioactivity-guided isolation and characterization be performed on these formulations to identify the possible active plant fractions or compounds. This will result in the exclusion of unnecessary or harmful compounds or fractions from the formulation. This will make the resulting formulation safer for consumers to use and even more effective in the treatment of typhoid due to higher concentrations of the active ingredients.

An assessment of the contraindications showed that all the products were contraindicated in pregnancy, lactating mothers and children below either 6 yrs or 12 yrs old. This is very useful in preventing possible toxicity in such vulnerable groups since very little or no toxicity studies may have been conducted in these sensitive groups of patients to ascertain the product safety. However due to the wide patronage of these products, both acute and chronic toxicity studies may need to be conducted in other groups of patients. This will also ascertain the safety of these products when used in other co-morbid conditions and age groups.

No artificial constituents whether in the form of active constituents and inactive constituents such as preservatives, flavours or sweeteners were indicated to be present in the products. This may raise the question as to whether the components of these formulations are anti-microbially active enough to preserve the products for their respective shelf lives and during the usage period. All the products were aqueous based and hence the high concentration of water makes them very prone to microbiological contamination not to mention the high incidence of the presence of several microbial pathogens in herbal products and their toxins [65].

A literature search performed on documented anti-typhoid activity of the plants used in formulating these preparations such as (Carica papaya [66], Vernonia amygdalina [67-69], Morinda lucida [35,36], Azadirachter indica [16] and Citrus aurantifolia [23] etc.) showed that their inclusion as active ingredients may be well justified.

A further literature search on the phytochemical constituents of the plants with the highest frequency Carica papaya, Morinda lucida, Citrus aurantifolia, Vernonia amygdalina, Azadirachta indica, Khaya senegalensis, Cassia alata and Momordica charantia (Group I, Table 1) showed that all the 8 plants contained flavonoids, while 7 contained alkaloids, 6 out of the eight plants contained tannins, saponins and glycosides as secondary metabolites [70-77]. The antityphoid activity may well be due to the presence of these phytoconstituents, but further studies may need to be done to ascertain this.

\section{CONCLUSIONS}

The active plant components of the anti-typhoidal formulations seem to be well justified and probably indicate that the resulting products could be highly active. The labeling of these products can also be improved in respect of the names of the active components and directive for dosage. Improvement can also be made in terms of formulation of the products to reduce the daily dosage and product volumes.

\section{CONSENT}

It is not applicable.

\section{ETHICAL APPROVAL}

It is not applicable.

\section{ACKNOWLEDGEMENTS}

The authors will like to thank the herbal medicinal shops and pharmacies which helped in collecting the herbal products, and also commend the Traditional Healers in Ghana who are the main innovators of such products.

\section{COMPETING INTERESTS}

Authors have declared that no competing interests exist.

\section{REFERENCES}

1. Hiroshi K, Hiroshi N. Structure of cell wall lipopolysaccharide from Salmonella 
typhimurium IV. Anomeric configuration of L-rhamnose residues and Its taxonomic implications. Journal of Bacteriology. 1973; 113:672-679.

2. Girgis NI, Butler T, Frenck RW, Sultan $\mathrm{Y}$, Brown FM, Tribble D, Khakhira R. Azithromycin versus ciprofloxacin for treatment of uncomplicated typhoid fever in a randomized trial in Egypt that included patients with multidrug resistance. Antimicrobial agents and Chemotherapy. 1999;43(6):1441-1444.

3. Ministry of Health Ghana. Standard treatment guidelines. Sixth Edition. 2010; 362-364.

4. Contreras I, Toro C, Troncoso G, Guido M. Salmonella typhi mutants defective in anaerobic respiration are impaired in their ability to replicate within epithelial cells. Microbiology. 1997;143:2665-2672.

5. World Health Organization. The world health report 1996: Fighting disease, fostering development. World Health Organization, Geneva, Switzerland. [PubMed].

6. Appiah-Korang Labi Obeng-Nkrumah $\mathrm{N}$, Addison NO, Donkor ES. Salmonella blood stream infections in a tertiary care setting in Ghana. BMC Infectious Diseases. 2014; 14:3857.

7. Kariuki S. Typhoid fever in sub-Saharan Africa. Challenges of diagnosis and management of infections. Journal of Infection in Developing Countries. 2008; 2(6):443-447.

8. Bhan MK, Bahl R, Bhatnagar S. Typhoid and paratyphoid fever. The Lancet. 2005;366(9487):749-762.

9. Sory E. The health sector in Ghana. Facts and figures. Ghana Health Service Accra, (Ghana). 2009;31.

10. WHO. Traditional Medicine. World Health Organization Fact Sheet No 134; 2003. Available:http://www.who.int/mediacentre/f actsheets/2003/fs134/en/

(Accessed on 11 August 2010)

11. Yarney J, Donkor A, Opoku SY, Yarney LAgyeman-Duah I, Abakah AC, Asampong E. Characteristics of users and implications for the use of complementary and alternative medicine in Ghanaian cancer patients undergoing radiotherapy and chemotherapy: A cross- sectional study. BMC Complementary and Alternative Medicine. 2013;13(16):1-9.
12. Ghana Statistical Service. 2010 Population and Housing Census. District analytical report. Ga east municipality; 2014.

13. Epidi JIO, Izah SC, Ohimain El. Antibacterial and synergistic efficacy of extracts of Alstonia boonei tissues. British Journal of Applied Research. 2016;1(1):2126.

14. Musa AD, Yusuf GO, Ojogbane EB, Nwodo OFC. Screening of eight plants used in folkloric medicine for the treatment of typhoid fever. Journal of Chemical and Pharmaceutical Research. 2010;2(2):7-15.

15. Eze VC, Omeh YN, Onwuakor CE, Enwemiwe $\mathrm{AO}$. In vitro qualitative and quantitative phytochemical analysis and antibacterial activities of ethanolic extracts of Anthocleista vogelii on some bacteria responsible for wound and enteric infection. International Journal of Pharmaceutical Sceinces Review Research. 2014;29(1):191-195.

16. Panchal $\mathrm{P}$, Bajaj $\mathrm{H}$, Maheshwari $\mathrm{S}$. Azadirachta indica (NEEM): Antibacterial effects against Escherichia coli and Salmonella. Journal of Pharmacy and Research. 2013;1(1):18-21.

17. Tsobou R, Mapongmetsem PM, Van Damme P. Medicinal plants used against typhoid fever in Bamboutos Division, Western Cameroon Roger. Ethnobotany Research and Applications. 2013;11:15473465-1511-1163.

18. Dongmo NA, Nganso DYO, Nkwensoua TE, Boda AM, Voundi OS, Etoafa FX, Nyasse S. In-vitro testing of extracts and fractions from two Cameroonian medicinal plants on bacteria gastroenteritis. American Journal of Phytomedicine and Clinical Therapeutics. 2015;3(9):575-588.

19. Nirosha N, Mangalanayaki R. Antibacterial activity of leaves and stem extracts of Carica papaya L. International Journal of Advances in Pharmacy, Biology and Chemistry. 2013;2(3):473-476.

20. Tsobou R, Mapongmetsem PM, Voukeng $\mathrm{KI}$, Van Damme P. Phytochemical screening and antibacterial activity of medicinal plants used to treat typhoid fever in Bamboutos division, West Cameroon. Journal of Applied Pharmaceutical Science. 2015;5(6):34-049.

21. Dahiru D, Malgwi AR, Sambo HS. Growth Inhibitory Effect of Senna siamea leaf extracts on selected microorganisms. American Journal of Medicine and Medical Sciences. 2013;3(3):103-107. 
22. Srividhya M, Ramanathan K, Krishnanand N. Efficacy of citrus fruit peel extracts against pathogens causing gastrointestinal disorders. International Journal of Pharmacy and Pharmaceutical Sciences. 2013;5:4

23. Aibinu I, Adenipekun T, Adelowotan T, Ogunsanya T, Odugbemi T. Evaluation of the antimicrobial properties, of different parts of Citrus aurantifolia (Lime furit) as used locally. African Journal of Traditional, Complementary and Alternative Medicines. 2007;4(2):185-190.

24. Enemor EC, Akagha TN, Ngwoke KG, Gugu TH,Oli AN, Eze CO, Ugwu BC, Ejikeugwu PC, Ugwu MC. Phytochemical analysis and antimicrobial activity of ethanolic stem extracts of Cnestis ferruginea on multidrug resistant bacteria isolated from raw retail meat sold in Awka, Nigeria. Journal of Pharmaceutical Sciences and Research. 2015;7(11):10441049.

25. Verma V, Bhardwaj A, Rathi S, Raja RB. A potential antimicrobial agent from Cocos nucifera mesocarp extract; Development of a new generation antibiotic ISCA. Journal of Biological Sciences. 2012;1(2):48-54.

26. Mills-Robertson FC, Aboagye AF, DukerEshun G, Kaminta S, Agbeve S. In vitro antimicrobial activity of Cryptolepis sanguinolenta (Periplocaceae). African Journal of Pharmacy and Pharmacology. 2009;3(9):476-480.

27. Yomi FO, Mohammed L, Zurmi SR. Ethnomedicinal survey of anti-typhoid plants in ljebu Ode Local Government Area of Ogun State, Nigeria. International Journal of Sceince and Nature. 2014;5(2): 332-336.

28. Akin-Osanaiye BC, Agbaji AS, Dakare MA. Antimicrobial activity of oils and extracts of Cymbopogon citratus (Lemon Grass), Eucalyptus citriodora and Eucalyptus camaldulensis. Journal of Medical Sciences. 2007;7:694-697.

29. Ugoh SC, Agarry OO, Garba SA. Studies on the antibacterial activity of Khaya senegalensis [(Desr.) A. Juss)] stem bark extract on Salmonella enterica subsp. enterica serovar Typhi [(ex Kauffmann and Edwards) Le Minor and Popoff]. Asian Pacific Journal of Tropical Biomedicine. 2014;4(4):279-S279.

30. African Regional Workshop (Conservation \& Sustainable Management of Trees, Zimbabwe, July 1996). 1998. Khaya ivorensis. The IUCN Red List of Threatened Species 1998; e.T32234A9689954.

Available:http://dx.doi.org/10.2305/IUCN.U K. 1998. RLTS.T32234A9689954.en

31. Salada JT, Balala LM, Vasquez EA. Phytochemical and antibacterial studies of Lantana camara L. leaf fracion and essential oil. International Journal of Scientific and Research Publications. 2015;5:5.

32. Azhagesan G, Rajan S, Soranam R. Antisalmonella activities of Mangifera indica seed kernel aqueous extract (MISKAE). Advances in Applied Science Research. 2015;6(5):75-80.

33. Sahrawat A, Pal S, Shahi SK. Antibacterial activity of Mangifera indica (mango) leaves against drug resistant bacterial strains. International Journal of Advanced Research. 2013;1(6):82-86.

34. Adeyi AO, Jinadu AM, Arojojoye OA, Alao OO, Ighodaro OM, Adeyi EO. In vivo and in vitro antibacterial activities of Momordica charantia on Salmonella typhi and its effect on liver function in typhoid-infected rats. Journal of Pharmacognosy and Phytotherapy. 2013;5(11):183-188.

35. Musa AD, Omale EO, Musa A, Nwodo OF. Anti-typhoid potentials of crude and fractions of defatted chloroform extract of Morinda lucida leaves. International Journal of Advanced Biotechnology Research. 2014;6(1):74-82.

36. Fakoya A, Owojuyigbe OS, Fakoya S, Adeoye SO. Possible antimicrobial activity of Morinda lucida stem bark, leaf and root extracts. African Journal of Biotechnology. 2014;13:3.

37. Okwori AEJ, Okeke $\mathrm{Cl}$, Uzoechina $\mathrm{A}$, Etukudoh NS, Amali MN, Adetunji JA, Olabode A. The antibacterial potentials of Nauclea latifolia. African Journal of Biotechnology. 2008;7(10):1394-1399.

38. Adebolu TT, Oladimeji SA. Antimicrobial activity of leaf extracts of Ocimum gratissimum on selected diarrhoea causing bacteria in southwestern Nigeria. African Journal of Biotechnology. 2005; 4(7):682-684.

39. Amengialue $\mathrm{OO}$, Edobor $\mathrm{O}$, Egharevba AP. Antibacterial activity of extracts of Ocimum gratissimum on bacteria associated with diarrhoea. Bayero Journal of Pure and Applied Sciences. 2013;6(2): 143-145. 
40. Maurice M. Iwu handbook of african medicinal plants, Second edition. February 4, 2014 by CRC Press.

ISBN: 9781466571976 - CAT\# K16569

41. Etienne Dongo, Hidayat Hussain, Renadin S. Miemanang, Dagobert Tazoo, Barbara Schulz, Karsten Krohn. Chemical Constituents of Klainedoxa gabonenses and Paullinia pinnata. Rec. Nat. Prod. 2009;3(3)165-169.

42. Ilozue NM, Ikezu UP, Ugwu Okechukwu PC. Anti-microbial and phytochemical screenin $g$ of the seed extracts of Persea americana (Avocado pear). Journal of Pharmacy and Biological Sciences (IOSRJPBS.). 2014;9(9):23-25.

43. Kavit M, Patel BN, Jain BK. Antimicrobial Activity of root extract of Phyllanthus fraternus Webster. An Ethnomedicinal plant. Research Journal of Recent Sciences. 2014;3(ISC-2013):275-278.

44. Etuk EU, Francis UU. Acute Toxicity and Efficacy of Psidium guajava leaves water extract on Salmonella typhi infected wistar rats. Pakistan Journal of Biological Sciences. 2003;6(3):195 -197.

45. Onocha PA, Otunla EO. Biological activities of extracts of Pycnanthus angolensis (Welw.) Warb. Archives of Applied Science Research. 2010;2(4):186190.

46. Fapojuwomi OA, Asinwa IO. Assessment of medicinal values of Rauwolfia vomitoria (Afzel) in Ibadan Municipality. Greener Journal of Medical Sciences. 2013;3:2.

47. Aromolaran O, Badejo OK. Efficacy of fresh leaf extracts of Spondias mombin against some clinical bacterial isolates from typhoid patients. Asian Pacific Journal of Tropical Disease. 2014;4(6):442-446.

48. Abu Asad Chowdhury, MS Islam. Antimicrobial activity of Trema orientalis. Dhaka Univ. J. Pharm. Sci. 2004;3:1-2. DOI: 10.3329/dujps.v3i1.186

49. Michael Buenor Adinortey, Isaac K. Galyuon, Nicholas Oteng Asamoah. Trema orientalis Linn. Blume: A potential for prospecting for drugs for various uses. Pharmacogn Rev. 2013;7(13):67-72. DOI: $10.4103 / 0973-7847.112852$

50. Chikwendu $\mathrm{Cl}$, Ebgadon E, Okuma B. Antibacterial potentials of Vernonia amygdalina against antibiotic-resistant Salmonella specie isolated from Nworie River, Imo State, Nigeria. International Letters of Natural Sciences. 2016;56: 82-89.
51. Ogbulie JN, Ogueke CC, Nwanebu FC. Antibacterial properties of Uvaria chamae, Congronema latifolium, Garcinia kola, Vernonia amygdalina and Aframomium melegueta. African Journal of Biotechnology. 2007;6:1549-1553.

52. Epidi JIO, Izah SC, Ohimain El, Epidi TT. Phytochemical, antibacterial and synergistic potency of tissues of Vitex grandifolia. British Journal of Applied Research. 2016;2:2.

53. Islam K, Rowsni AA, Khan M, Kabir S. Antimicrobial activity of ginger (Zingiber officinale) extracts against food-borne pathogenic bacteria. International Journal of Science, Environment and Technology. 2014;3(3):867-871.

54. Falconer J. Non-timber forest products in Southern Ghana. Ghana Forestry Department and Overseas Development Administration (ODA); 1994.

55. van Andel $\mathrm{T}$, Myren $\mathrm{B}$, van Onselen $\mathrm{S}$. Ghana's herbal market. Journal of Ethnopharmacology. 2012;140(2):368-78.

56. Kunle OF, Egharevba HO, Ahmadu PO. Standardization of herbal medicines - A review. International Journal of Biodiversity and Conservation. 2012;4(3):101-112.

57. Institute for safe Medication Practices. Move toward full use of metric dosing: Eliminate dosage cups that measure liquids in fluid drams. Use cups that measure $\mathrm{mL}$. National Alert Network (NAN). June 30; 2005.

Available:https://www.ismp.org/NAN/files/N AN-20150630.pdf

58. Sanjoy KP, Yogoshwer S. Herbal Medicine: Current status and the future. Asian Pacific Journal of Cancer Preview. 2003;4:281-288.

59. Kareru PG, Kenju GM, Gachanja AN, Keriko JM, Mungai G. Traditional Medicines Among the Embu and Mbeere Peoples of Kenya. African Journal of Traditional, Complementary, and Alternative Medicines. 2007;4(1):75-86.

60. Biswas SAS, Singh P, Chandra S. Neem (Azadirachta indica A. Juss.) - a Versatile Multipurpose Tree. The Indian Forester. 1995;121:11.

61. Yeap SK, Ho WY, Liang WS, Huynh KY, Hadi A, Yousr N, Alitheen NB. Vernonia amygdalina, an ethnoveterinary and ethnomedical used green vegetable with multiple bio-activities. Journal of Medicinal Plants Research. 2010;4(25): 2787-2812. 
62. Alam S, Asad M, Asdaq SM, Prasad VS. Antiulcer activity of methanolic extract of Momordica charantia L. in rats. Journal of Ethnopharmacology. 2009;123(3):464-469.

63. Ministry of Health. Anti-malaria drug policy for Ghana; 2009.

64. Rasoanaivo $\mathrm{P}$, Wright $\mathrm{CW}$, Willcox $\mathrm{ML}$, Gilbert B. Whole plant extracts versus single compounds for the treatment of malaria: Synergy and positive interactions. Malaria Journal. 2011;10:(Suppl 1:S4).

65. Gupta KK, Prasad G, Chopra AK, Khana DR. Contamination of Asian herbal drugs: Needs fro tis critical evaluation. Journal of Applied and Natural Science. 2009;1(2): 291-297.

66. Aravind G, Bhownik D, Duraivel S, Harish G. Traditonal and Medicinal Uses of Carica papaya. Journal of Medicinal Plant Studies. 2013;1:1.

67. Bukar AM, Isa MA, Bello HS, Abdullahi AS. Antibacterial activity of aqueous and ethanolic leaf extracts of Vernonia amygdalina on selected species of Grampositive and Gram negative bacteria. International Journal of Evironment. 2013; 2:1.

68. Yar'adua Al, Shuaibu L, Nasir A. Phytochemical and antibacterial investigation of leaf extracts of Vernonia amygdalina. British Microbiology Research Journal. 2015;10(1):1-6.

69. Alo MN, Anyim C, Igwe JC, Elom M, Uchenna DS. Antibacterial activity of water, ethanol and methanol extracts of Ocimum gratissimum, Vernonia amygdalina and Aframomum melegueta. Advances in Applied Science Research. 2012;3(2):844-848

70. Adachukwu PA, Ogbonna AO. Faith UE. Phytochemical analysis of paw-paw (Carica papaya) leaves. International
Journal of Life Sciences Biotechnology and Pharma Research. 2013;2(3):347351.

71. Oikeh El, Omoregie ES, Oviasogie FE, Oriakhi K. Phytochemical, antimicrobial, and antioxidant activities of different citrus juice concentrates. Food Sci Nutr. 2016; 4(1):103-109.

72. Hossaina MA, Al-Toubia WAS, Welia AM, Al-Riyamia QA, Al-Sabahib JN. Identification and characterization of chemical compounds in different crude extracts from leaves of Omani neem. Journal of Taibah University for Science. 2013;7(4):181-188.

73. Falodun A, Obasuyi O. Phytochemical screening and evaluation of stem bark extract of Khaya senegalensis (Meliaceae) on methicillin resistant Staphylococcus aureus. Canadian Journal of pure and applied sciences. 2009;3(3):925-928.

74. Olabiyi TI, Oyedunnmade EEA, Ibikunle J. Phytochemical Screening and Nematoxic Effect of Brimstone, Morinda lucida, on nematode pests of Amaranth, Celosia argentea. Biological Agriculture \& Horticulture. 2008;26(2):131-137.

75. Farombi EO, Owoeye O. Antioxidative and chemopreventive properties of Vernonia amygdalina and Garcinia biflavonoid. International Journal of Environmental Research and Public Health. 2011;8(6): 2533-2555.

76. Okooboh AM, Ndam G. Phytochemistry and antimicrobial activity of the leaf of Cassia alata LINN. Chemistry and Materials Research. 2013;3:3.

77. Prarthna D, Ujwala S, Roymon MG. A review on Phytochemical analysis of Momordica charantia. International Journal of Advances in Pharmacy. Biology and Chemistry. 2014;3(1):214-220.

(c) 2017 Bekoe et al.; This is an Open Access article distributed under the terms of the Creative Commons Attribution License (http://creativecommons.org/licenses/by/4.0), which permits unrestricted use, distribution, and reproduction in any medium, provided the original work is properly cited.

Peer-review history:

The peer review history for this paper can be accessed here: http://sciencedomain.org/review-history/19439 